\title{
COMMUNICATION
}

Cite this: DOI:

$10.1039 / \times 0 \times x 00000 x$

\section{One-step protecting-group-free synthesis of azepinomycin in water}

\author{
Adam J. Coggins, ${ }^{a}$ Derek A. Tocher ${ }^{a}$ and Matthew W. Powner ${ }^{a^{*}}$
}

Received 00 th January 2012 ,

Accepted 00 th January 2012

DOI : $10.1039 / x \odot \times x \odot \odot \odot \odot \odot x$

www.rsc.org/

We report an efficient, atom economical general acid-base catalyzed one-step multi-gram synthesis of azepinomycin from commercially available compounds in water. We propose that the described pH-dependent Amadori rearrangement, which couples an amino-imidazole and simple sugar, is of importance as a potential step toward predisposed purine nucleotide synthesis at the origins of life.

Nucleotides and nucleic acids are compounds of privileged biological importance and, consequently, nucleotide and nucleobase analogues have found great importance in pharmaceutical chemistry. ${ }^{1}$<smiles>NC(=O)c1ncn(P)c1N</smiles><smiles>O=CCO</smiles><smiles>Oc1ccc(O)cc1</smiles>

AICA R=H AICAR R=ribosyl 1 1<smiles>O=C1NC(O)CNc2c1ncn2P</smiles>

$2 \mathrm{R}=\mathrm{H}$ 5 R=ribosyl $\mathrm{pH} 4.0$<smiles>NC(=O)c1ncn(P)c1/N=C/CO</smiles>

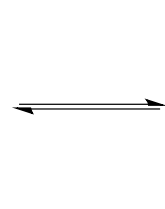

Scheme 1: Protecting-group-free synthesis of azepinomycin $2(R=H)$ and azepinomycin riboside 5 ( $R=\beta$-D-ribofuranosyl) in water. $N$-Acyl-hemiaminal $N-H$ shown bold.
Here we demonstrate an amino-imidazole tethering strategy that uses an Amadori rearrangement, which couples glycolaldehyde (1) to 5-aminoimidazole-4-carboxamide (AICA), and consequently the synthesis of azepinomycin (2), ${ }^{2}$ a guanine deaminase inhibitor isolated from the culture filtrate of Streptomyces $s p$ (Scheme 1) containing an $N$-acyl hemiaminal synthesized by direct conjugation of an aldehyde and amide in neutral water. ${ }^{2,3}$ We propose that this could have been a key step in the regiospecific coupling of purine precursors to sugars at the onset of biology, before the advent of enzymatically-controlled biosynthesis.

The synthesis of 5-amino-imdiazole-4-carbonitrile (AICN) and AICA from hydrogen cyanide tetramer (DAMN) was demonstrated more than 60 years ago by a remarkable photochemical rearrangement (Scheme 2). ${ }^{4}$ Further chemical elaboration of AICN and AICA to the canonical purine nucleobases has been reported, however poor selectivity and very low yields for purine nucleobases ribosylation with free sugars ${ }^{5}$ has cast doubt upon the plausibility of purine nucleoside synthesis by direct glycosylation of nucleobases. ${ }^{6,7}$



Scheme 2: Oligomerisation of hydrogen cyanide to diaminomaleonitrile (DAMN) and subsequent photochemical isomerisation and hydrolysis to 5amino-imidazole-4-carbonitrile (AICN) and 5-amino-imidazole-4carboxamide (AICA)

The great difficulties incurred by ribosylation of purine nucleobases and observed intermediacy of 5-amino-imidazole-4-carboxamide riboside (AICAR) in de novo purine synthesis have led to our interest in the reactivity of AICA to develop new strategies to tether sugars and purine precursors. ${ }^{7,8}, 9$ Specifically, we have previously proposed that the 1,5-disposition of the 
imidazole and amine moieties of AICA provide the inherent regioselectivity required to deliver the correct $N 7$-ribosylation of purine nucleotides in the absence of sophisticated enzymatic control. We have previously demonstrated $\mathrm{pH}$-controlled multicomponent coupling of AICA, aldehydes and 2-amino-azoles that leads to regiospecific coupling of AICA (by the correct N1-nitrogen atom) to masked tetrose and pentose sugars in excellent yields. ${ }^{8}$ Here we report a complementary tethering strategy for AICA and $\mathbf{1}$ by Amadori rearrangement in neutral aqueous phosphate buffer. The nature of the reaction conditions, the compounds (AICA and 1) and the remarkable efficiency and selectivity signify the potential importance of the reaction in elucidating the chemical origins of life.

Four syntheses of azepinomycin (2) have previously been reported. Isshiki et al. reported both seven- and six-step sequences to 2 in $5 \%$ or $6 \%$ overall yield, respectively. ${ }^{2}$ Fuji et al. reported an eleven-step sequence to yield $\mathbf{2}$ in $5 \%$ overall yield. ${ }^{10}$ Finally, in 2012, Hosmane and co-workers reported a seven-step synthesis providing access to $\mathbf{2}$ in $16 \%$ yield from AICAR. ${ }^{11}$

During the course of studying of the chemical origins of ribonucleotides we noted that $\mathbf{2}$ is, constitutionally, a conjugate of glycolaldehyde (1) and AICA. We had previously observed both highly efficient trapping of AICA as Schiff bases 3 in water ${ }^{8,9}$ and the remarkable efficacy of phosphate, acting as a general acid-base catalyst, mediating neutral-pH proton transfer. ${ }^{12}$ Our analysis of $\mathbf{2}$ suggested that, under conditions when rapid tautomerisation of imine $\mathbf{3}$ and aldehyde $\mathbf{4}$ was observed, $\mathbf{2}$ would be a privileged chemical structure, accessible in one protecting-group-free step from commercially available reagents by sequential imine formation, Amadori rearrangement and amine-tethered dehydration.

Pleasingly, incubation of AICA (0.08M) and $1(0.15 \mathrm{M})$ in aqueous $1 \mathrm{M}-$ phosphate buffer at $60^{\circ} \mathrm{C}$ for $24 \mathrm{~h}$ gave a facile and near quantitative synthesis of $\mathbf{2}$ in $83 \%$ yield. Purification of $\mathbf{2}$ (pKa 4.2; see supplementary information) can be conveniently achieved by solid-phase extraction with ion-exchange resin (proton-form Dowex® 50W) and liberation of 2 from Dowex $\AA$ is then achieved at $\mathrm{pH} \geq 7$ to give a $1.16 \mathrm{~g}(80 \%)$ isolated yield of $\mathbf{2}$. Heterocycle 2 can then be further purified by (unoptimized) recrystallisation to afford crystalline 2 in $60 \%$ yield after one protecting-group-free step without any requirement for chromatography. ${ }^{\dagger}$

${ }^{1} \mathrm{H}-\mathrm{NMR}$ studies indicate that the $\mathrm{N}$-acyl hemiaminal $\mathrm{N}-\mathrm{H}$ bond of 2 (Scheme 1; $\mathbf{N}-\mathbf{H}$ shown bold) exchanges slowly and is observed as a doublet ( ${ }^{1} \mathrm{H}$ NMR $\left.\left(\mathrm{H}_{2} \mathrm{O}: \mathrm{D}_{2} \mathrm{O}, 10: 1\right) \delta_{\mathrm{H}} 8.06 \mathrm{ppm}, J=5.6 \mathrm{~Hz}\right)$ in ${ }^{1} \mathrm{H}-\mathrm{NMR}$ spectra acquired of $\mathrm{H}_{2} \mathrm{O}$ solutions of $\mathbf{2}\left({ }^{1} \mathrm{H}\right.$ NMR spectra of $\mathbf{2}$ in DMSO, $\mathrm{H}_{2} \mathrm{O}: \mathrm{D}_{2} \mathrm{O}$ (10:1), $\mathrm{D}_{2} \mathrm{O}$ are provided in Supplementary Information). The slow exchange of $\mathrm{N}$-acyl hemiaminals has been observed previously and attributed to intramolecular hydrogen bonding, ${ }^{13}$ however the bicyclic architecture of $\mathbf{2}$ prohibits intramolecular hydrogen bonding suggesting inductive or stereoelectronic inhibition of proton-exchange in $\mathbf{2}$. Evidence of an anomeric effect is provided by the axial position of hemiaminal moiety in crystal structure (Figure 1). ${ }^{\dagger}$



Figure 1: Single crystal X-ray structure of azepinomycin (2) crystallised from aqueous ethanol $\left(\mathrm{H}_{2} \mathrm{O}: \mathrm{EtOH}\right.$ 9:1).
En route to 2, Hosmane et al. isolated the two diastereomeric ribosides $\mathbf{5}$ in a combined $27 \%$ yield. ${ }^{11}$ Though it was predicted that ribosylation of $\mathbf{2}$ may improve bioactivity, it was observed to diminish guanine deaminase inhibitor activity. Though our primary goal was to establish the chemical reactivity of AICA and 1, we thought it imperative to also investigate the reactivity of AICAR. Firstly, to demonstrate the stability of the glycosidic bond of AICAR under the conditions that facilitate Amadori rearrangement, and secondly, to investigate the potential derivatisation of AICAR. AICAR Amadori rearrangement provides a rapid, protectinggroup-free method to access $\mathbf{5}$, however could be highly detrimental to further development of purine nucleotide synthesis under phosphate buffer reaction conditions.

Interestingly, we observed no reaction between AICAR and 1 in $\mathrm{pH}$ 6phosphate buffer. Indeed, $\mathbf{1}$ was completely consumed in a slow homoaldol/Lobry de Bruyn-Alberda van Ekenstein rearrangement over the course of $4-5$ days at $60^{\circ} \mathrm{C}$ to give erythulose, whereas AICAR (within the limits of ${ }^{1} \mathrm{H}-\mathrm{NMR}$ detection) remain unaltered by phosphate buffer or glycolaldehyde-modification at $\mathrm{pH} 6.5 .^{\ddagger}$ We hypothesise that the change in $\mathrm{pKa}^{14}$ of AICAR relative to the aglycone, AICA, prohibited iminium formation and, therefore, protected AICAR from derivatisation by inhibition of the Amadori rearrangement. Interestingly, with respect to further elaboration of purine ribonucleotides, the switch in reactivity observed protects AICAR from subsequent (undesirable) derivatisation by the aldehydic precursors of nucleotides in phosphate buffer.

In support of our hypothesis that the observed $\mathrm{pK}_{\mathrm{a}}$ shift protects AICAR from derivatisation at neutral $\mathrm{pH}$, we found that Amadori rearrangement of AICA and 1 was not observed at $\mathrm{pH}>8$. Consequently, we proposed that Amadori rearrangement of AICAR would be observed at low $\mathrm{pH}$. We were pleased to observe that at $\mathrm{pH} 3-4$ in phosphate or acetate buffer, conversion of AICAR to $\mathbf{5}$ was indeed switched on, such that in aqueous solution at $\mathrm{pH} 4$ preparation of 5 could be achieved in $50-65 \%$ yield over $3-4$ days at $60^{\circ} \mathrm{C}$ directly from AICAR. The equilibrating diastereomers of $\mathbf{5}\left(\mathrm{H}_{2} \mathrm{O}, 1.2: 1\right){ }^{11}$ were then isolated by solid-phase extraction with ion-exchange resin (proton-form Dowex ${ }^{\circledR} 50 \mathrm{~W}$ ) and separated for individual analysis by preparative RP-HPLC.

\section{Conclusions}

We have demonstrated a high-yielding, atom-economical, chromatography-free, and protecting-group-free strategy for the synthesis of azepinomycin (2). Additionally, we described the $\mathrm{pH}$ dependence of aminoimidazole-glycolaldehyde Amadori rearrangement leading to deferential synthesis of azepinomycin ribosides (5) and azepinomycin (2).

Importantly, with respect to the origins of life, these results demonstrate highly effective sugar- $C 2$ - (5-amino)-imidazole tethering of carbohydrates and 5-aminoimidazoles, which are important purine nucleobase precursors. An investigation of the predisposed ${ }^{15}$ Amadori rearrangement towards the origin of purine ribonucleotides in biology is underway in our laboratory.

\section{Experimental}

Glycolaldehyde dimer was purchased from Sigma-Aldrich, 5aminoimidazole-4-carboxamide (AICA) was purchased from Acros 
Organics, and AICA-riboside (AICAR) was purchased from Fluorochem. Solvents were obtained from Fischer Scientific. All reagents and solvents were used without further purification. Dowex 50WX8 200-400 mesh ion exchange resin was purchased from Acros Organics and was washed with methanol and sodium hydroxide solution before being regenerated with hydrochloric acid solution. NMR spectra were recorded on either a Bruker $600 \mathrm{MHz}$ or Oxford 400 MHz spectrometer in $\mathrm{D}_{2} \mathrm{O}$, DMSO- $d 6$ or a mixture of $\mathrm{H}_{2} \mathrm{O}$ and $\mathrm{D}_{2} \mathrm{O}$ and chemical shifts are reported in ppm, referenced to the residual solvent signals. Mass spectrometry was carried out on a Waters LCT Premier XE spectrometer. HPLC was carried out on an Agilent 1260 system with a Polaris 5 C18-A analytical $(150 \times 4.6 \mathrm{~mm})$ or semi-preperative $(150 \times 10 \mathrm{~mm})$ column at $30^{\circ} \mathrm{C}$ with injection volumes of 5 or $100 \mu \mathrm{L}$ $(10 \mathrm{mg} / \mathrm{mL})$ and flow rates of 1 or $5 \mathrm{~mL} / \mathrm{min}$ respectively.

\section{Azepinomycin 2}

A solution of 5-aminoimidazole-4-carboxamide hydrochloride AICA $(1.38 \mathrm{~g}, 8.5 \mathrm{mmol})$ and glycolaldehyde dimer $(0.90 \mathrm{~g}, 15 \mathrm{mmol})$ in aqueous sodium phosphate $(1 \mathrm{M}, 100 \mathrm{~mL}, \mathrm{pH}$ 6) was prepared and incubated at $60^{\circ} \mathrm{C}$ for $24 \mathrm{~h}$. The solution was diluted to $500 \mathrm{~mL}$ with water and run through a column of Dowex ${ }^{\circledR} 50 \mathrm{WX} 8$ ion exchange resin $\left(\mathrm{H}^{+}\right.$form, ca. $\left.300 \mathrm{~mL}, 1.7 \mathrm{meq} / \mathrm{mL}\right)$ and the resin was then washed with 1 bed volume of water. The resin was suspended in water (300 $\mathrm{mL}$ ), the $\mathrm{pH}$ was raised to $\mathrm{pH} 7$ with sodium hydroxide (4M) and the suspension was filtered. The resin was further washed with water and the combined filtrate and washings were lyophilised. The resulting solid was dried over $\mathrm{P}_{2} \mathrm{O}_{5}$ giving $2(1.16 \mathrm{~g}, 80 \%)$ as a fine cream powder. A portion $(1.0 \mathrm{~g})$ of material was further purified by crystallisation from water:ethanol $(1: 1,20 \mathrm{~mL})$ at $0^{\circ} \mathrm{C}$. The solids were collected by filtration and washed with ice-cold ethanol and then diethyl ether giving an off white solid $(0.6 \mathrm{~g}, 60 \%)$. Analytical samples of x-ray quality crystals were obtained by vapour diffusion of ethanol into an aqueous solution of compound 2. $\mathrm{R}_{\mathrm{f}}: 0.24\left(\mathrm{CH}_{2} \mathrm{Cl}_{2}: 1 \% \mathrm{NH}_{3}\right.$ in $\mathrm{MeOH}, 5$ : 3). M.p. $194-230^{\circ} \mathrm{C}$ (dec) [lit. $208-220^{\circ} \mathrm{C}$ (dec.) $]^{10}$. IR $\left(\mathrm{cm}^{-1}\right)$ $3285(\mathrm{NH}) ; 3105 \mathrm{br}(\mathrm{OH}) ; 2279,2823(\mathrm{CH}) ; 1592,1546(\mathrm{C}=\mathrm{O}, \mathrm{C}=\mathrm{N})$. ${ }^{1} \mathrm{H}$ NMR (600 MHz, DMSO) $\delta_{\mathrm{H}} 11.83$ (1H, br s, N1-H); 7.75 (1H, d, $J$ $=5.6 \mathrm{~Hz}, \mathrm{~N} 9-\mathrm{H}) ; 7.32(1 \mathrm{H}, \mathrm{d}, J=1.1 \mathrm{~Hz}, \mathrm{C} 2-\mathbf{H}) ; 6.28(1 \mathrm{H}, \mathrm{dd}, J=5.6$, $2.2 \mathrm{~Hz}, \mathrm{~N} 6-\mathrm{H}) ; 5.39(1 \mathrm{H}, \mathrm{d}, J=5.6 \mathrm{~Hz}, \mathrm{OH}) ; 4.74(1 \mathrm{H}, \mathrm{q}, J=5.6 \mathrm{~Hz}$, C8-H); 3.36 (signal obscured by HDO peak, C7- $\left.\mathbf{H}_{\mathbf{a}}\right) ; 2.87(1 \mathrm{H}, \mathrm{dd}, J=$ 13.2, $\left.2.2 \mathrm{~Hz}, \mathrm{C} 7-\mathrm{H}_{\mathbf{b}}\right) .{ }^{1} \mathrm{H}$ NMR $\left(600 \mathrm{MHz}, \mathrm{D}_{2} \mathrm{O}: \mathrm{H}_{2} \mathrm{O}\right.$ 1:10) $\delta_{\mathrm{H}} 8.05$ $(0.5 \mathrm{H}, \mathrm{br} d, 5.6 \mathrm{~Hz}, \mathrm{~N} 9-\mathrm{H}) ; 7.58(1 \mathrm{H}, \mathrm{s}, \mathrm{C} 2-\mathrm{H}) ; 5.16(1 \mathrm{H}, \mathrm{t}, J=5.6 \mathrm{~Hz}$, C8-H); $3.69\left(1 \mathrm{H}, \mathrm{dt}, J=13.8,5.6 \mathrm{~Hz}, \mathrm{C} 7-\mathbf{H}_{\mathbf{a}}\right) ; 3.12(1 \mathrm{H}, \mathrm{d}, J=13.8 \mathrm{~Hz}$, C7-H $\left.\mathbf{H}_{\mathrm{b}}\right) .{ }^{1} \mathrm{H}$ NMR $\left(600 \mathrm{MHz}, \mathrm{D}_{2} \mathrm{O}\right) \delta_{\mathrm{H}} 7.59(1 \mathrm{H}, \mathrm{s}, \mathrm{C} 2-\mathrm{H}) ; 5.16(1 \mathrm{H}, \mathrm{d}$, $J=5.6 \mathrm{~Hz}, \mathrm{C} 8-\mathbf{H}) ; 3.70\left(1 \mathrm{H}, \mathrm{dd}, J=13.8,5.6 \mathrm{~Hz}, \mathrm{C} 7-\mathbf{H}_{\mathbf{a}}\right) ; 3.13(1 \mathrm{H}, \mathrm{d}$, $\left.J=13.8 \mathrm{~Hz}, \mathrm{C} 7-\mathbf{H}_{\mathrm{b}}\right) .{ }^{13} \mathrm{C} \mathrm{NMR}(150 \mathrm{MHz}, \mathrm{DMSO}) \delta_{\mathrm{C}} 161.3$ (q, C10); 150.8 (q, C5); 136.2 (CH, C2); 105.5 (q, C4); 72.6 (CH, C8); 48.5 $\left(\mathrm{CH}_{2}, \mathrm{C} 7\right)$. UV-vis: $\lambda_{\max }\left(\mathrm{H}_{2} \mathrm{O}, \mathrm{pH} 8\right) 287 \mathrm{~nm}(\varepsilon$ 9100). m/z (EI+) 168 $\left(100 \%,\left[\mathrm{M}^{+}\right]\right) ; 169\left(92 \%,\left[\mathrm{M}+\mathrm{H}^{+}\right]\right) ; 95$ (38\%); 123 (29\%); 68 (26\%); $122(25 \%) 140(25 \%) 151(20 \%)$. HRMS $\mathrm{C}_{6} \mathrm{H}_{8} \mathrm{~N}_{4} \mathrm{O}_{2}$ calcd. 168.06473, found 168.06512 .

N1-( $\beta$-D-ribofuranosyl)-(8R)-azepinomycin $\quad 5_{A} \quad$ and $\quad N 1-(\beta-D-$ ribofuranosyl)-(8S)-azepinomycin $5_{B}$

A solution of AICAR (200 mg, $0.75 \mathrm{mmol})$ and glycolaldehyde dimer (450 mg, $7.5 \mathrm{mmol})$ in aqueous sodium phosphate $(1 \mathrm{M}, 7.9 \mathrm{~mL}, \mathrm{pH} 6)$ was prepared and incubated at $60^{\circ} \mathrm{C}$ for $96 \mathrm{~h}$. The solution was diluted with water $(16 \mathrm{~mL})$ and passed through a column of Dowex ${ }^{\circledR} 50 \mathrm{WX} 8$ ion exchange resin $\left(\mathrm{H}^{+}\right.$form, ca. $\left.50 \mathrm{~mL}, 1.7 \mathrm{meq} / \mathrm{mL}\right)$, which was subsequently washed with water $(100 \mathrm{~mL})$. The resin was then removed from the column, suspended in water and the $\mathrm{pH}$ was adjusted to $\mathrm{pH} 7$ with sodium hydroxide $(4 \mathrm{M})$. The suspension was filtered and the resin washed with water $(100 \mathrm{~mL})$. The combined filtrate and washings were lyophilised returning crude $\mathbf{5}(180 \mathrm{mg})$ as a mixture of diastereoisomers. A small sample of this material was subjected to semi-preparative HPLC (isocratic water), returning each of the diastereomers (retention times 3.9 and $4.9 \mathrm{~min}$, respectively) as fine white powders after lyophilisation.

5. ${ }^{1} \mathrm{H}$ NMR $\left(600 \mathrm{MHz}, \mathrm{D}_{2} \mathrm{O}\right) \delta_{\mathrm{H}} 7.59(1 \mathrm{H}, \mathrm{s}, \mathrm{C} 2-\mathrm{H}) ; 5.70(1 \mathrm{H}, \mathrm{d}, J=$ $\left.6.0 \mathrm{~Hz}, \mathrm{C1} 1^{\prime}-\mathbf{H}\right) ; 5.17(1 \mathrm{H}, \mathrm{d}, J=5.4 \mathrm{~Hz}, \mathrm{C} 8-\mathbf{H}) ; 4.64(1 \mathrm{H}, \mathrm{t}, J=6.0 \mathrm{~Hz}$, C2'-H); $4.37\left(1 \mathrm{H}, \mathrm{dd}, J=6.0,3.2 \mathrm{~Hz}, \mathrm{C}^{\prime}-\mathbf{H}\right) ; 4.22(1 \mathrm{H}, \mathrm{q}, J=3.2 \mathrm{~Hz}$, C4'-H); $3.89\left(1 \mathrm{H}, \mathrm{dd}, J=12.6,3.2 \mathrm{~Hz}, \mathrm{C}^{\prime}-\mathbf{H}_{\mathbf{a}}\right)$; $3.85(1 \mathrm{H}, \mathrm{dd}, J=12.6$, $\left.3.2 \mathrm{~Hz}, \mathrm{C}^{\prime}-\mathbf{H}_{\mathbf{b}}\right) ; 3.76\left(1 \mathrm{H}, \mathrm{dd}, J=14.0,5.4 \mathrm{~Hz}, \mathrm{C} 7-\mathbf{H}_{\mathbf{a}}\right) ; 3.21(1 \mathrm{H}, \mathrm{d}, J$ $\left.=14.0 \mathrm{~Hz}, \mathrm{C} 7-\mathbf{H}_{\mathbf{b}}\right) \cdot{ }^{13} \mathrm{C}$ NMR $\left(150 \mathrm{MHz}, \mathrm{D}_{2} \mathrm{O}\right) \delta_{\mathrm{C}} 167.2(\mathrm{C} 10) ; 144.1$ (C5); 133.4 (C2); 114.4 (C4); 88.8 (C1'); 85.9 (C4'); 73.0 (C2'); 72.8 (C8); 70.9 (C3'); 61.5 (C5'); 47.7 (C7). m/z (ES+) 301 (100\%, $\left.\left[\mathrm{M}+\mathrm{H}^{+}\right]\right)$. HRMS $\mathrm{C}_{11} \mathrm{H}_{17} \mathrm{~N}_{4} \mathrm{O}_{6}$ calcd. 301.1148, found 301.1150 .

5. $_{\text {в. }} 1 \mathrm{H} \mathrm{NMR}\left(600 \mathrm{MHz}, \mathrm{D}_{2} \mathrm{O}\right) \delta_{\mathrm{H}} 7.60(1 \mathrm{H}, \mathrm{s}, \mathrm{C} 2-\mathrm{H}) ; 5.66(1 \mathrm{H}, \mathrm{d}, J=$ $\left.5.7 \mathrm{~Hz}, \mathrm{C} 1^{\prime}-\mathbf{H}\right) ; 5.18(1 \mathrm{H}, \mathrm{d}, J=5.8 \mathrm{~Hz}, \mathrm{C} 8-\mathbf{H}) ; 4.68(1 \mathrm{H}, \mathrm{t}, J=5.7 \mathrm{~Hz}$, C2'-H); $4.36\left(1 \mathrm{H}, \mathrm{dd}, J=5.7,3.4 \mathrm{~Hz}, \mathrm{C}^{\prime}-\mathbf{H}\right) ; 4.23(1 \mathrm{H}, \mathrm{q}, J=3.4 \mathrm{~Hz}$, C4'-H); $3.85\left(1 \mathrm{H}, \mathrm{dd}, J=12.8,3.4 \mathrm{~Hz}, \mathrm{C}^{\prime}-\mathbf{H}_{\mathbf{a}}\right) ; 3.80(1 \mathrm{H}, \mathrm{dd}, J=12.8$, $\left.3.4 \mathrm{~Hz}, \mathrm{C}^{\prime}-\mathbf{H}_{\mathbf{b}}\right) ; 3.77\left(1 \mathrm{H}, \mathrm{dd}, J=14.0,5.8 \mathrm{~Hz}, \mathrm{C} 7-\mathbf{H}_{\mathbf{a}}\right) ; 3.22(1 \mathrm{H}, \mathrm{d}, J$ $\left.=14.0 \mathrm{~Hz}, \mathrm{C} 7-\mathbf{H}_{\mathbf{b}}\right) \cdot{ }^{13} \mathrm{C}$ NMR $\left(150 \mathrm{MHz}, \mathrm{D}_{2} \mathrm{O}\right) \delta_{\mathrm{C}} 167.1(\mathrm{C} 10) ; 144.6$ (C5); 132.9 (C2); 114.0 (C4); 88.2 (C1'); 85.9 (C4'); 73.3 (C2'); 72.8 (C8); 71.0 (C3'); 61.6 (C5'); 47.7 (C7). m/z (ES+) 301 (100\%, $\left[\mathrm{M}+\mathrm{H}^{+}\right]$). HRMS $\mathrm{C}_{11} \mathrm{H}_{17} \mathrm{~N}_{4} \mathrm{O}_{6}$ calcd. 301.1148, found 301.1146 .

\section{Notes and references}

This work was supported by an EPSRC Fellowship (EP/K004980/1) and Simons Foundation Investigator grant (318881). We also posthumously thank Harry Lonsdale for an award from the Origin of Life Challenge.

${ }^{a}$ University College London, 20 Gordon Street, London WC1H 0AJ, UK. E-mail: matthew.powner@ucl.ac.uk

$\dagger$ Cell packing and intermolecular hydrogen bond diagrams are provide in Supplementary Information. The $N$-acyl hemiaminal $\mathrm{N}-\mathrm{H}$ is the only $\mathrm{N}-\mathrm{H}$ not involve in intermolecular a hydrogen bond in the crystal lattice. CIF available free of charge from the Cambridge crystallographic data centre: CCDC deposit \# 1034270.

$\$$ Glycolaldehyde (1) derivatisation of AICAR and AICA was not observed above $\mathrm{pH} 5$ and $\mathrm{pH} 8$ respectively, however deuterium exchange at imidazole-C2 carbon atom is observed in $\mathrm{D}_{2} \mathrm{O}$.

Electronic Supplementary Information (ESI) available: Product spectra, reaction spectra, $\mathrm{pH}$-titration and crystallographic data and plots are provided in supplementary information. See DOI: 10.1039/c000000x/

1 E. De Clercq, Pharmacol. Toxicol. 2011, 51, 1; E. De Clercq, A. Holy, Nature Rev. Drug Discov. 2005, 4, 928.

2 K. Isshiki, Y. Takahashi, H. Iinuma, H. Naganawa, Y. Umezawa, T. Takeuchi, H. Umezawa, S. Nishimura, N. Okada, K. Tatsuta, $J$. Antibiot. 1987, 40, 1461.

$3 \mathrm{~N}$-Acyl hemiaminals are found in a number of isolated natural products. ${ }^{3 a-3 e}$ Synthetic methods for the preparation of $N$-acyl hemiaminals are limited. ${ }^{3 f-3 m, 13}$ Direct condensation of aldehydes with 
amides is typically restricted to highly electron-deficient aldehydes ${ }^{\mathrm{f}, \mathrm{g}}$ and in general furnish $N, N^{\prime}$-alkylidene bisamides. ${ }^{\text {hi }}$ (a) $\mathrm{C}$. Kellerjuslen, M. Kuhn, H.R. Loosli, T. J. Petcher, H.P. Weber, A. V. Wartburg Tetrahedron Lett. 1976, 17, 4147. (b) M. Konishi, K. Saito, K. Numata, T. Tsuno, K. Asama, H. Tsukiura, T. Naito, H. Kawaguchi J. Antibiot. 1977, 30, 789. (c) H. Umezawa, S. Kondo, H. Iinuma, S. Kunimoto, Y. Ikeda, H. Iwasawa, D. Ikeda, T. Takeuchi $J$. Antibiot. 1981, 34, 1622. (d) S. Kondo, H. Iwasawa, D. Ikeda, Y. Umeda, Y. Ikeda, H. Iinuma, H. Umezawa J. Antibiot. 1981, 34, 1625. (e) N. B. Perry, J. W. Blunt, M. H. G. Munro, L. K. Pannell J. Am. Chem. Soc. 1988, 110, 4850. (f) M. Sasaki, M. Tsuda, M. Sekiguchi, Y. Mikami, J. Kobayashi Org. Lett. 2005, 7, 4261. (g) A. Schouteeten, Y. Christidis, G. Mattioda Bull. Soc. Chim. Fr. 1978, 2, 248. (h) A. H. Fernandez, R. M. Alvarez, T. M. Abajo Synthesis 1996, 1299. (i) L. Ingrassia, M. Mulliez Synthesis 1999, 1731. (j) D. Labrecque, S. Charron, R. Rej, C. Blais, S. Lamothe Tetrahedron Lett. 2001, 42, 2645. (k) A. B. Smith III, I. G. Safonov R. M. Corbett J. Am. Chem. Soc. 2001, 123, 12426. (1) T. R. Hoye, M. Hu J. Am. Chem. Soc. 2003, 125, 9576. (m) S. Kiren, N. Shangguan, L. J. Williams Tetrahedron Lett. 2007, 48, 7456.

4 J. Oro, BioChem. Biophys. Res. Commun. 1960, 2, 407; C. U. Lowe, M. W. Rees, R. Markham, Nature 1963, 199, 219; J. P. Ferris, L. E. Orgel, J. Am. Chem. Soc. 1966, 88, 3829; J. P. Ferris, L. E. Orgel, J. Am. Chem. Soc. 1966, 88, 1074; R. A. Sanchez, J. P. Ferris, L. E. Orgel, J. Mol. Biol. 1967, 30, 223.

5 W. D. Fuller, R. A. Sanchez, L. E. Orgel, J. Mol. Evol. 1972, 1, 249.

6 C. Anastasi, F. F. Buchet, M. A. Crowe, A. L. Parkes, M. W. Powner, J. M. Smith, J. D., Sutherland, Chem. Biodiv. 2007, 4, 721.

7 M. W. Powner, J. D. Sutherland, J. W. Szostak, Synlett 2011, 14, 1956.

8 M. W. Powner, J. D. Sutherland, J. W. Szostak, J. Am. Chem. Soc. 2010, 132, 16677.

9 M. W. Powner, S.-L. Zheng, J. W. Szostak, J. Am. Chem. Soc. 2012, 134, 13889.

10 T. Fuji, T. Saito, T. Fujizawa, Chem. Pharm. Bull. 1994, 42, 1231; T. Fujii, T. Sato, T. Itaya, Chem. Pharm. Bull. 1971, 19, 1731; T. Fuji, T. Saito, T. Fujisawa, Heterocycles 1988, 27, 1163.

11 S. Chakraborty, N. H. Shah, J C. Fishbein, R. S. Hosmane, Bioorg. Med. Chem. Lett. 2012, 22, 7214.

12 M. W. Powner, B. Gerland, J. D. Sutherland, Nature, 2009, 459, 239; M. W. Powner, J. D. Sutherland, Angew Chem. Int. Ed. 2010, 49, 4641.

13 J. C. Bussolari, K. Beers, P. Lalan, W. V. Murray, D. Gauthier, P. McDonnell Chem. Lett. 1998, 787-788; D. M. Troast, J. A. Porco Jr. Org. Lett. 2002, 4, 991.

14 pKa: AICA $=5.4 ; 2$ = 4.2; AICAR = 3.3; J. H. Shim, M. Wall, S. J. Benkovic, N. Díaz, D. Suárez, K. M. Merz Jr. J. Am. Chem. Soc. 2001, 123, 4687.

15 A. Eschenmoser, E. Loewenthal, Chem. Soc. Rev. 1992, 21, 1. 